\title{
Factors Impacting EFL Teachers' Self-efficacy: A Theoritical Perspective
}

\author{
Nasir Mehmood ${ }^{1}$ \\ ${ }^{1}$ Faculty of Languages \& Translation, King Khalid University, Abha, Saudi Arabia \\ Correspondence: Nasir Mehmood, Faculty of Languages \& Translation, King Khalid University, Abha, Saudi \\ Arabia
}

Received: January 18, 2019 Accepted: March 5, 2019 Online Published: March 8, 2019

doi: 10.5539/elt.v12n4p39 URL: https://doi.org/10.5539/elt.v12n4p39

\begin{abstract}
EFL teachers working in Saudi Arabian universities are often from different social, cultural and academic backgrounds. The factors that affect their self-efficacy can vary from one teacher to another because of their different social and cultural associations. This research is carried out in the light of the existing literature to determine some of the factors and variables which may influence the level of EFL teachers' self-efficacy who teach at the universities in Saudi Arabia. Some of the factors are related to the personal traits of the teachers such as competence, experience, flexibility, hard work, perseverance, motivation, attitude, self-efficacy, resourcefulness and how they see themselves as teachers; whereas others are associated with their cultural, social and academic background, the working environment of an organization, and the attitudes of learners. Teacher self-efficacy is prone to be affected either negatively or positively by all these factors.
\end{abstract}

Keywords: EFL context, EFL teacher, self-efficacy theory, teacher learning, development, learners' achievements, motivation

\section{Introduction}

Teaching English as a foreign language can be challenging in Saudi Arabia which is a monolingual country where English is used sparsely and usually the learners' background in English language is weak. Therefore, it's crucial that teachers teaching in such environment are adept with the quality of self-efficacy. High level of self-efficacy will enable EFL teachers to persevere in circumstances where they have to deal with unmotivated and disinterested learners. The process of teaching and learning can get worse if there is a lack of motivation - either on the part of teachers or learners. Therefore, it is necessary for both to be highly motivated so that learning can take place effectively.

The objective of this paper is to see the influence of teacher self-efficacy on the process of teaching and learning. Also, to know in what ways teacher self-efficacy can affect the performance of EFL teachers. To determine some influential factors and variables that can possibly affect teacher self-efficacy in negative or positive way, and finally; to find out the effect of transformational and transactional leadership on teacher self-efficacy.

There are many factors related to the concept of teacher self-efficacy, but only those relevant to the context of this research are discussed in guidance of the existing literature. Moreover, due to the limitations of space and time, it was not possible to discuss all the aspects of teacher self-efficacy in this research paper.

To begin with, according to the idea of teacher self-efficacy, a teacher is the pivot of learning; therefore, his or her belief in his or her ability to make learning happen may go a long way. Teachers with high sense of self-efficacy have great determination and show great perseverance in the face of adversities which may hinder the process of effective teaching. They don't give in quickly while dealing with slow learners; rather they focus more on the students who are slow learners and lag behind in the process of learning.

Generally speaking, teachers with high level of self-efficacy are more flexible in changing their teaching strategies and adopting differnet methodologies according to the needs of their learners. If one method of teaching does not achieve the intended goal, they turn to another. They simlply do not stuck only to one strategy. Self-efficaciuos teachers are good with maneovuring their methods and strategies inside the classroom which makes them extremely resourceful. Their teaching revolves around the needs of the students, not their personal satisfaction which makes them absolutely professional teachers. 


\section{A Background of the Evolution of the Theory of Self-efficacy}

Before giving an account of the theory of self-efficacy, it is important to know how it evolved in order to have a better understanding of the idea. The concept of self-efficacy evolved from social cognitive theory (SCT) which has its roots in social learning theory (SLT). The two theories are closely related. SCT can be termed as an extension of SLT. The range and scope of SCT is much broader than that of SLT because SLT focuses only on external factors whereas SCT focuses both on external and internal factors.

\section{Social Learning Theory (SLT) vs. Social Cognitive Theory (SCT)}

In the 1960's, Albert Bandura developed social learning theory which had its basis in behaviorism. According to SLT, interaction with people and observing them were mainly the social context of learning (Bandura, 1977; Pajares, 2002). With a purpose to redefine and differentiate the theory of social learning (SLT) from the prevailing behaviorist theories of the time, Bandura renamed it as social cognitive theory (SCT) in 1986. The emphasis of SCT is on cognitive variables in social interaction and learning and how these variables influence the behavior of the people involved in the interaction (Pajares, 2002). Social cognitive theory connects human behavior with learning by laying emphasis on the role of self-beliefs (self-efficacy) unlike social learning theory that focuses only on external factors (Bandura, 1977, 1989, 1997).

Social cognitive theory is an expansion of behaviorism which limits the whole course of human actions to stimuli and reinforcement mechanism. In addition to accepting environmental factors as having influences on behavior, SCT incorporates cognitive processes and people's behavior to self-discipline themselves on the basis of the information they get from their experiences. Bandura (1986) showed a triangular relationship between cognitive factors, environmental factors, and behavioral factors that affect human behavior. These factors work together at the same time to influence people's cognitive behavior through the development of self-efficacy (Bandura, 1986).

\section{Self-efficacy as an Outcome of Social Cognitive Theory}

Self-efficacy is one of the crucial principals of social cognitive theory. According to Bandura (1986), "People's judgments of their capabilities to organize and execute courses of actions required to attain designated types of performances" (p.391). Self-efficacy can have either positive or negative influence on people's ways of doing things. Bandura (1994) states that people who believe they can achieve a goal or accomplish a task have a high sense of self-efficacy. They are well-nigh to do so because they are willing to initiate a behavior to persevere through difficulties that they may face in the process of accomplishing the task. It has been found that during the last 40 years, teacher self-efficacy has had a remarkable influence on the quality of classroom environments and student and teacher outcomes (TschannenMoran \& Woolfolk Hoy, 1998, 2001; Zee \& Koomen, 2016).

\section{The Evolution of the Concept of Teacher Self-efficacy:}

The Rand Corporation (Armor et al., 1976) first started the research on self-efficacy in the 1970's. The research is deeply rooted in in locus of control (Rotter, 1966) or social cognitive theory (Bandura, 1977). Bandura (1977) exercised a major influence over teacher self-efficacy research by introducing the concept of self-efficacy to social cognitive theory. Bandura's 1977 theory of self-efficacy triggered teacher self-efficacy research which focused on "need to differentiate between self-efficacy and outcome expectancies" (Zee \& Koomen, 2016, p. 984), and it focused on the concept that self-efficacy is basically task-specific and can vary between classrooms, content areas, students, and other environmental variables. Self-efficacy is independent of outcome expectancy which is a belief about a behavior that can lead to a specific outcome. The two have different effects on bahvaior change.

\section{What Is Teacher Self-efficacy?}

Teacher self-efficacy is defined as teachers' confidence in their ability to promote learning. This quality enables them to plan, organize and execute a task successfully (Tschannen-Moran, Woolfolk-Hoy, \& Hoy, 1998). This belief of teachers, according to research, has direct relationship with the students' achievement, (e.g., McLaughlin \& Marsh, 1978) and students' motivation, (e.g., Midgley, Feldlaufer, \& Eccles, 1989). It also exhibits a teacher having value of educational innovations, (e.g., Cousins \& Walker, 2000) his classroom management skills (Woolfolk, Rosoff, \& Hoy, 1990), and a teacher's focus (Greenwood, Olejnik, \& Parkay, 1990). Self-efficacy is a characteristic which makes teachers more flexible in dealing with classroom problems. They are more ready to adopt new techniques and methodologies to cope up with difficult and tough situations. Teachers with this trait are more willing to deal with unmotivated students and show resilience towards failures and setbacks. Teacher self-efficacy has positive influence on teachers' performance and makes their teaching effective. Self-efficacious teachrs are determined and persevere to achieve the goals they set for themselves. In 
the field of pedagogy, teacher self-efficacy has a vital role.

\section{Processes by Which Self-Efficacy Influences Behavior}

Bandura (1994) asserts that four processes (cognitive processes, motivational processes, affective processes, and selection processes) influence human behavior through self-efficacy. They can be termed as efficacy-activated processes because they are triggered by self-efficacy. These processes show the effect of self-efficacy on human behavior and the way it functions. The level of efficacy is directly related to have either positive or negative effect on one's attitude, motivation, anxiety, or the decision to pursue an opportunity or challenge (Bandura, 1994).

\subsection{Cognitive Processes}

In Bandura's (1994) view, before the execution of any difficult or challenging task, a plan of execution is mapped out in thoughts. Self-efficacy can influence these cognitive processes a great deal. People with high level of self-efficacy are more inclined to take challenges because they draw a successful and positive image of themselves to complete the task. As a result, they are more likely to be consistent in proceeding through challenges and will find the means to achieve their goals. People with low self-efficacy on the other hand see failure through their mental eye before starting a difficult task which increases their chance of falling short of achieving their objectives. Because of doubting their potentials and envisioning failure, they either avoid the challenge they face or get a setback when they attempt it without trusting themselves. Bandura (1994) puts it as, "It is difficult to achieve much while fighting self-doubt" (p. 4).

\subsection{Motivational Processes}

Motivational processes are closely connected with cognitive processes through forethought and predictions about how things will happen in future. For people of high self-efficacy, their past failures are due to their lack of making enough efforts. Consequently, they work with more perseverance and higher motivation for achieving a goal they set for themselves the next time. In contrast, people with low self-efficacy perceive their lack of ability as the main cause of their failure which weakens their motivation and determination. In the face of adversity, their motivation is low and their perseverance is weak (Bandura, 1989).

\subsection{Affective Processes}

It's people's trust in their ability to overcome an obstacle or difficult situation, and their control of their thinking which affects the level of stress or anxiety in tough situations in their lives. High level of self-efficacy results in the formation of a positive outlook which gives way to positive thoughts. Whereas low level of self-efficacy makes one to "magnify the severity of possible threats" (Bandura, 1994, p. 5) and develop defeatist thought patterns."

\subsection{Selection Processes}

Selection processes, like the other processes, are also dependant on self-efficacy. People are generally inclined to put themselves in situations where they are sure about their success. High sense of self-efficacy imparts people with the quality to accept challenges in their life. Even if they lack the potential, their high level of motivation and perseverance enables them to make for their shortcomings and achieve their target successfully. On the other hand, people with low level of self-efficacy try to avoid a difficult situation; or worse yet, they may decide against undertaking a task if they are not sure about its accomplishment (Bandura, 1989).

Self-efficacy heavily depends on all the processes mentioned above and play a fundamental role in how people think, behave, and tackle tasks and challenges. Bandura (1994) also mentions four sources which influence self-efficacy either in positive or in negative ways.

\section{Sources of Self-efficacy}

Bandura (1977, 1997) posited four main sources of self-efficacy: mastery experiences, psychological and emotional states, vicarious experiences and social persuasions. All the sources are interconnected. They can influence each other and occur simultaneously. Sources of self-efficacy can have both positive and negative influence on EFL teachers' self-efficacy depending on their teaching experiences.

\subsection{Mastery Experiences}

Mastery experiences are considered to be the most powerful source of self-efficacy. These are the opportunities people avail to accomplish a difficult and challenging task. As a result, they establish a conviction that an obstacle can be overcome through hard work. This theory can be applied to teaching in general and EFL teaching in particular by an assumption that those teachers who had successful experiences with learners in the past will 
anticipate the same in the future. They will plan and make strategies in the light of their past experiences to be successful with their teaching in the future. Their expectation of success will increase their self-efficacy and enhance the level of their level of confidence. In contrast, teachers with a low sense of instructional efficacy tend to believe that they can do but little in the development of the students with low achievements who are negatively affected from their homes and environments (Bandura, 1997, p. 240).

\subsection{Vicarious Experiences}

The second source of self-efficacy is 'vicarious experiences' which means that people are inclined to be influenced by observing the successes and failures of others through social modals. The success and failure of a peer may influence the course of their action. Confidence in people's own ability is increased when they see a peer of their capability succeed by his or her expertise and perseverance (Bandura, 1994; Pajares, 2002). Seeing the accomplishments of other people will have an efficacious effect on people (Bandura, 1982; Gist, 1987; Gist, Schwoerer, \& Rosen, 1989 and 1982). But it may produce a negative effect on their self-efficacy if people see their peer unsuccessful despite his or her hard work and perseverance. It is to be noted here that a peer or a social model must be considered similar to oneself to have the influence of vicarious experiences on self-efficacy. If a social modal is viewed different from oneself, no effect on self-efficacy is likely to be produced. In addition, a peer must be competent enough to demonstrate the execution of a task the observer aspires to master (Bandura, 1994; Swanson, 2012).

\subsection{Social Persuasion}

Humans are part of society and are connected with one another through some relationships. Their lives are dependent on one another. Self-efficacy is boosted when one person encourages another person by telling him that he or she is capable of accomplishing a task. For example, a father would wish his son to succeed in his life, and for that he will support him - both morally and materially. He will try to encourage his son by telling him that he is competent enough to pass a test or get a job. Similarly, teachers may encourage their students to uplift their morale so that they perform well in their exams. People feel more confident to overcome an obstacle when persuaded by others to believe that they have the ability to do so. Verbal or social persuasion is the verbal reassurance or encouragement that people get from other people (relatives, friends, teachers etc.) who are related to them in some way. This source of self-efficacy may go a long way in one's life. The purpose of social persuasion should be the improvement of an individual instead of comparing him or her with someone else (Bandura, 1994; Swanson, 2012).

\subsection{Emotional \& Physiological States}

One of the many qualities that God has gifted human beings with, and which make them distinct from animals, is the ability to react emotionally to the situations that surround them. A person's mood and somatic condition can have an impact on his or her level of self-efficacy. One can be happy, sad, stressed, relaxed or worried depending on the situation one is in. The way people react to a situation can affect their level of confidence. Stress and anxiety, for instance, will diminish their level of self-efficacy which in turn will affect their performance. The feelings of nervousness and the fear of failure can be perceived as signs of vulnerability which lower a person's belief that he or she can perform a task successfully (Bandura, 1994). According to Pajares, (2002) people have the ability to control their emotions and thinking to an extent. Their having high level of self-efficacy in aforementioned three factors can produce a positive influence in controlling their physiological reactions.

It has been observed that efficacious teachers do not get confused easily by a difficult or unwanted situation that arises unexpectedly in the classroom. They rather handle it with confidence and find a way out successfully. They control their emotions and do not get anxious or confused. In contrast, teachers with a low sense of efficacy may easily get perturbed by a difficult circumstance for which they may not be mentally prepared before hand. The rigidness of low self-efficacy teachers can be a barrier in way of overcoming any difficulty that concerns the class management or students' behavior.

\section{High Sense of Self-efficacy vs. Low Sense of Self-efficacy}

Studies show that teachers with a high sense of instructional efficacy spend more time on instructional activities, and try to help weak students to succeed in accomplishing the task. Teachers with low sense of instructional efficacy on the other hand, utilize their time in other activities than learning. They are impatient with slow learners and give up easily. Instead of helping the slow learners, they rebuke them for their errors (Bandura, 1997, p. 241). Low self-efficacy teachers are more inclined to be authoritarian by nature. Their main concern is about keeping discipline in the classroom. They are strict and use rigid disciplinary rules in the classroom and depend on external or extrinsic motivation which is reward or punishment driven behavior. Instead of motivating them, a 
teacher with low sense of self-efficacy uses negative restrictions to keep the students working (Bandura, 1997, p. 241).

Bandura (1997) finds out that students perform better with high self-efficacy teachers than with the teachers who have low sense of self-efficacy. Efficacious teachers believe theycan help the slow learners by giving them some more work whereas low efficacy teachers take low grades for low student ability.

Self-efficacy is useful for solving problems inside the classroom. Teachers of high self-efficacy addresse the problems in the classroom immediately and comes up with a solution because of their flexibility. On the contrary, teachers with low efficacy try to ignore the classroom problems for the sake of having better feelings.

Self-efficacy also depends on what the success is attributed to. Success will enhance self-efficacy if it is attributed to personal traits such as competence and hard work. Self-efficacy won't increase in any remarkable quantity if the success is associated with luck or others' intervention (Bandura, 1993; Pintrich \& Schunk, 1996).

\section{Advantages of High Teacher Self-Efficacy}

How teacher self-efficacy and students' achievements measures and students' motivation are associated, has been the subject matter of many studies (Guo, McDonald Connor, Roehring, \& Morrison, 2012; Khan, 2012; Mohamadi \& Asadzadeh, 2012; Ross, 1994; Thoonen, Sleegers, Oort, Peetsma, \& Geijsel, 2011; Woolfolk Hoy \& Davis, 2005). As a result, it has been found that teacher self-efficacy has a positive influence on students' motivation and achievements. Teacher self-efficacy is believed to have contributed to an increase in students' achievements indirectly as it influences teachers' planning, teaching, reflecting, and conceptualization of instruction. Similarly, students' achievement gains are also attributed to teacher self-efficacy as an indirect consequence of higher quality instruction (Guo et al., 2012; Holzberger, Phillip, \& Kunter, 2013; Woolfolk Hoy \& Davis, 2005; Wyatt, 2016).

A literature review was carried out by Zee and Koomen (2016) on studies that investigated teacher self-efficacy in various dominions of the classroom. They reached at the conclusion that "teachers with high general self-efficacy have been demonstrated to perceive the implementation of new instructional methods as more important and congruent with their own practices" (p. 991). The outcome of this review coincides with Bandura's definition of self-efficacy, the efficacy-activated processes, and the four self-efficacy factors that posit that people who believe they can accomplish a challenging task are more inclined to attempt it. Another longitudinal study was conducted by Holzberger, Philipp, and Kunter (2013) that focused on the teacher self-efficacy levels of 155 in-service teachers and the quality instruction over a span of one year. Holzberger et al. (2013) concluded that there exists interdependency between teacher self-efficacy and the instructional quality, and that throughout the school years; there had been alterations in the levels of self-efficacy.

Moreover, it has been proved by research that teachers do benefit from the quality of high self-efficacy. Research on both novice and experienced teachers have shown that having high level of teacher self-efficacy decreased job stress and increased job satisfaction (Barouch Gilbert, Adesope, \& Schroeder, 2013; Canrinus, Helms-Lorenz, Beijaard, Buitink, \& Hofman, 2012; Klassen, Usher, Bong, 2010; von der Embse, Sandilos, Pendegast, \& Mankin, 2016). There is a correlation between the findings of these studies and Bandura's (1994) propositions that self-efficacy influences "choices, level of motivation, quality of functioning, resilience to adversity and vulnerability to stress" (p. 15).

\section{Variables of Teacher Self-efficacy}

Although teacher self-efficacy is crucial for effective teaching and learning process, but it can be hard to understand the complicated nature of relationship between teacher self-efficacy and its variables. The variables of teacher self-efficacy may differ from one individual to another depending on his or her social background, cognitive behaviour, intrinsic and extrinsic motivation, level of competence and knowledge, working environment, learners' motivation and achievements etc. Teacher self-efficacy is associated with various teaching behaviors and students' achievement of success (Ashton \& Webb, 1986; Gibson \& Dembo, 1984; Ross, 1992) and motivation (Midgley, Feldlaufer, \& Eccles, 1989; Woolfolk, Rosoff, \& Hoy, 1990). It can also be related with teacher's classroom management approaches (Henson, 2001; Woolfolk \& Hoy, 1990).

\subsection{Novice vs. Experienced Teachers}

Research on both novice and experienced teachers have shown that having high teacher self-efficacy decreased job stress and increased job satisfaction (Barouch Gilbert, Adesope, \& Schroeder, 2013; Canrinus, Helms-Lorenz, Beijaard, Buitink, \& Hofman, 2012; Klassen, Usher, Bong, 2010; von der Embse, Sandilos, Pendegast, \& Mankin, 2016). 
Mastery experiences, which come from a teacher's successful past experiences of teaching with his students, have the most powerful influence on teachers' self-efficacy beliefs. These experiences give teachers a sense of achievement which raises their level of self-efficacy. They feel more confident about the success of their future accomplishments too for which they plan and organize more effectively. Because a novice teacher has fewer mastery experiences, it can be predicted that his or her level of efficacy would be lower than that of an experienced teacher.

Novice teachers enter the profession of teaching with great zeal and enthusiasm. At the beginning of their carrier, they show great zeal and enthusiasm to have an impact on their students, but they get an embarrassing set back by their students' performance which does not come up to their expectations. It's a reality shock for them to realize that it may be more difficult to achieve the desired results with students (Weinstein, 1988). This may compel a novice teacher to re-evaluate the meaning of good teaching and bring his standards down for the sake of defending himself from being self-evaluated as unsuccessful teacher. On the other hand, a teacher's doubts about the effectiveness of his teaching can motivate him to continue learning and growth if he has a firm belief in the possibility of future success (Wheatley, 2002)

\subsection{The Effect of the Students' Motivation and Achievement on Teacher Self-efficacy}

Teacher self-efficacy can be, to some extent, directly related to students' achievement (Ashton \& Webb, 1986; Gibson \& Dembo, 1984; Ross, 1992). According to Bandura (1997, p. 399), the most important and powerful source of efficacy are enactive mastery experiences or 'performance attainments'. A teacher is expected to have a high level of motivation if he or she has motivated students who are keen to achieve the goals or objectives their teacher sets for them. Learners' motivation can have a boosting up effect on teacher self-efficacy. Moreover, highly motivated students will do better learning and give good output which will elevate teacher's sense of achievement. This will also be an 'enactive mastery experience' for a teacher. On the other hand, unmotivated students with low achievements will have a negative effect on teacher self-efficacy. Therefore, it can be presumed that unmotivated students can affect teacher self-efficacy negatively beause the learners' performance doesn't come up to the teacher's expectations. Inspiring students with low or no motivation can be extremely challenging and requires constant efforts from a teacher to uplift their level of interest in the process of learning.

\section{The Influence of Transformational \& Transactional Leadership on Teacher Self-efficacy}

Efforts are needed to support teacher self-efficacy in dealing with every day stressors. The current scenario is more demanding for EFL teachers as they are required to pay more attention to individual needs of their students; therefore, teachers need to be provided with opportunities for professional growth as they strive to cope up with the challenges they are confronted with. For this purpose, teachers need a strong support and cooperation from the administration. Workshops, seminars and training programs can be arranged on regular basis where more experienced teachers share their experiences with less experienced teachers. Teachers and leaders can form unified learning communities for continuous support of teachers. Not only will these communities help teachers to grow in their profession, but also they will feel more valued as professional.

The concept of transformational development was first used by James MacGregor Burns (1978) in his descriptive research on political leadership. This term is now used in organizational psychology too. Burns stated that "leaders and followers help each other to advance to a higher level of morale and motivation". Burns differentiated between management and leadership. He asserted that the main differences are between characteristics and behaviors. He presented two concepts: "transforming leadership" and "transactional leadership". In Burns view, transforming approach of leadership brings about drastic change in the life of people and the organizations. It restructures perceptions and values and changes the expectations and aspirations of employees. On the other side, transactional approach is mainly based on 'give and take' relationship; not on the leader's personality, traits and ability to bring about a positive change by setting challenging goals for his or her followers. Leadership in transactional approach does not strive for cultural change in organization whereas transformational leadership works for changing organizational culture. That is why, transformational leadership can play a formidable role in increasing teachers' self-efficacy. For achieving high level of self-efficacy in teachers, there is a strong need for emotional support in the form of positive feedback and encouragement from transformational style of leadership. The efforts of committed teachers are "affected by the type of leadership that administrators exhibit" (Ware \& Kitsantas, 2007, p. 304). Transformational leadership set itself as a role model for their followers. It strives to transform its followers into leaders by enhancing their motivation, morale and performance through a variety of mechanisms. This type of leadership challenges its followers by giving them more responsibility of their work and tries to understand their strengths and weaknesses, and positively inform them about their weaknesses for the purpose of their professional developments. 


\section{Psychological Implications of Transformational and Transactional Leadership and Their Effect on Teacher Self-efficacy}

Bernard M. Bass (1985), a researcher, furthered the work of Burns (1978) by giving a psychological explanation of the psychological mechanism that underlies transforming and transactional leadership. Burns (1978) also explained the parameters by which transformational leadership could be measured, and the impact it has on its followers' motivation and performance. How much transformational a leader is, can be measured by his or her influence on the followers who will harbor for him or her feelings of trust, loyalty and admiration. They will respect him or her and will be willing to work harder than they are actually expected to. The reason for this is that transformational leaders do not work only for personal gains. They transform and motivate their followers through their idealized influence, intellectual stimulation and individual consideration. They also encourage them to be innovative in changing the challenging environment for success. In the end, Bass suggested that leadership can adopt both transformational and transactional approaches depending on the requirement of an organization.

\section{Author's Reflective Account of Self-efficacy as an EFL Teacher}

In the light of the current literature on teacher self-efficacy, I would like to relate some of my personal experiences and observations. One of the most important variables of teacher self-efficacy is his or her mastery experiences - a teacher's successful past experiences with teaching - learning process are likely to increase his self-efficacy. But imagine a teacher who starts his or her career in an institution where throughout his or her career he or she has to deal with unmotivated learners whose achievements have been low consistently despite the teacher's efforts and hard work. What sort of impact will this have on his or her self-efficacy if he or she has never had any remarkable successful experience with his students - neither in his or her past nor in his or her present? It can jar his or her sense of self-efficacy, no matter how motivated and determined teacher he or she is. This is an extraordinary situation which is faced by majority of EFL teachers at university level in Saudi Arabia; and which I think is worth mentioning in this research paper. EFL teachers face this difficult situation due to having low learners who have been promoted to a higher level without learning the basics they were supposed to learn at school. Their certificates simply do not represent their competence. It has been Sisyphus's rolling stone for teachers to motivate these students to learn to achieve enactive mastery experience. Except from a few students, it is almost impossible for a majority of them to fill in this gap of learning. As a result, the the students mostly fall short of achieving the goal set for them by their teachers. This is the reason majority of students are unmotivated and lack self-efficacy which in turn affects teacher self-efficacy. Situation of this type can be avoided by improving the standard of learning at lower levels, and by setting certain standards for promotion in order to make sure the authenticity of learners' certificate which must reflect their competence.

\section{Conclusion}

Teacher self-efficacy is the belief a teacher has in his ability to promote learning. Teachers with this quality enjoy certain advantages in various dominions of the classroom. They are flexible enough to adopt and try different ways of teaching in order to accomplish a challenging task in the classroom.

Self-efficacy can also influence behavior through cognitive, motivational, affective and selection processes.

Sources of efficacy such as mastery experiences, vicarious experiences, social persuasion and physiological states can also impact teacher self-efficacy. Another important determiner of teacher self-efficacy is its variables (social background, cognitive behavior, intrinsic and extrinsic motivation, level of competence and knowledge, working environment, learners' motivation and achievements etc.) which can vary from one individual to another.

A distinction has been made through the identification of certain characteristics which differentiate between teachers of high and low level of self-efficacy. It is found that high self-efficacy teachers have certain characteristics which teachers with low self-efficacy lack. For example, teachers of high self-efficacy are flexible with their students and are patient with slow learners, whereas teachers with low self-efficacy are rigid, strict and impatient with slow learners. Additionally, teachers with high level of self-efficacy have certain advantages over low self-efficacy teachers. They have positive influences on students' motivation and achievements. They are willing to change their strategies according the requirements or needs of their students.

Teacher self-efficacy also depends if a teacher is a novice or an experienced teacher. An experienced teacher has more mastery experiences than a novice teacher which gives him a sense of achievement. Resultantly, by mastery experiences he will achieve high level of self-efficacy that is also reciprocated in students' achievements.

Transformational leadership has a great effect on EFL teacher self-efficacy. A transformational leader supports his followers and encourages and helps them to achieve the challenging goals they set for them. Transforming leadership approach turns their followers into leaders by constantly developing their professional skills through 
consistent training. Transforming leadership approach can create a convivial environment for teaching - learning process and can help ESL teachers to develop professionally which will increase their level of self-efficacy.

Teacher self-efficacy is such a broad term that it is hardly possible to cover its all dimensions in this research. Therefore, only some of the factors of ESL teacher self-efficacy have been discussed with a purpose to know the sort of effect they may produce on their self-efficacy. The factors are chosen on the basis of their relevance to the context of a Saudi Arabian University.

Further research is needed in the area of EFL teacher self-efficacy to determine the factors that demotivate the students at the level of university in Saudi Arabia and cause low level of self-efficacy among EFL teachers. Most of the students who get promotion from schools to the university with high grades are found out very weak in English at the level of the university by the EFL teachers to their shock because the grades of the students do not reflect their competence. To put it more directly, the level of the competence of the students is not a true representation of their grades. EFL teachers find it almost impossible to motivate these students because their knowledge of English language is almost zero. Dealing with such students can have an extremely negative effect on ESL teachers' self-efficacy. At the end of the term, the teachers receive a painful shock from low achievements of their students which have a negative impact on their self-efficacy. In addition, there is also a dire need for a research on to find flaws in the testing system at school level which award students of such a low level with such high grades, and also to find ways to improve it, so that the negative impact of unmotivated students on ESL teacher self-efficacy can be minimized at university level.

\section{References}

Ashton, P. T., \& Webb, R. B. (1986). Making a difference: Teachers' sense of efficacy and student achievement. New York: Longman.

Bandura, A. (1977). Self-efficacy: Toward a unifying theory of behavioral change. Psychological Review, 84, 191-215. https://doi.org/10.1037/0033-295X.84.2.191

Bandura, A. (1982). Self-efficacy mechanism in human agency. American Psychology, 37, 122-147. https://doi.org/10.1037/0003-066X.37.2.122

Bandura, A. (1986). Social foundations of thought and action: A social cognitive theory. Englewood Cliffs, NJ: Prentice Hall.

Bandura, A. (1989). Social cognitive theory. In R. Vasta (Ed.), Annals of child development: Six theories of child development (pp. 1-60). Greenwich, CT: JAI Press.

Bandura, A. (1993). Perceived self-efficacy in cognitive development and functioning.

Bandura, A. (1994). Self-efficacy. In V. S. Ramachaudran (Ed.), Encyclopedia of human behavior (Vol. 4, p. 71-81). New York: Academic Press. (Reprinted in H. Friedman [Ed.], Encyclopedia of mental health. San Diego: Academic Press, 1998).

Bandura, A. (1997). Self-efficacy: The exercise of control. New York: W.H. Freeman.

Barouch Gilbert, R., Adesope, O. O., \& Schroeder, N. L. (2014). Efficacy beliefs, job satisfaction, stress and their influence on the occupational commitment of Englishmedium content teachers in the Dominican Republic. Educational Psychology, 34(7). https://doi.org/10.1080/01443410.2013.814193

Burns, J. M. (1978). Leadership. New York. Harper \& Row.

Baumrind, D. (1989). Sex-differentiated Socialization effects in childhood and adolescence, Paper presented at the biennial meeting of the Society for Research in Child Development, Kansas City.

Canrinus, E. T., Helms-Lorenz, M., Beijaard, D., Buitink, J., \& Hofman, A. (2012). Selfefficacy, job satisfaction, motivation and commitment: Exploring the relationships between indicators of teachers' professional identity. European Journal of Psychology of Education, 27(1), 115-132. https://doi.org/10.1007/s10212 $-011-0069-2$

Cousins, J. B., \& Walker, C. A. (2000). Predictors of educators' valuing of systematic inquiry in schools. Canadian Journal of Program Evaluation, Special Issue, 25-53.

Eccles, J. S. (1987). Gender roles and achievement patterns: An expectancy value perspective. In J. M. Reinisch, L. A. Rosenblum, \& S. A. Sanders (Eds), Masculinity / femininity: Basic perspectives. New York: Oxford University Press. 
Gibson, S., \& Dembo, M., (1984). Teacher efficacy: A construct validation. Journal of Educational Psychology, 76(4), 569-582. https://doi.org/10.1037/0022-0663.76.4.569

Greenwood, G. E., Olejnik, S. F., \& Parkay, F. W. (1990). Relationships between Four Teacher Efficacy Belief Patterns and Selected Teacher Characteristics.

Guo, Y., Justice, L.M., Swayer, B., \& Tompkins, V. (2011). Exploring factors related to preschool teachers' self-efficacy. Teaching and Teacher Education, 27(1), 961-968. https://doi.org/10.1016/j.tate.2011.03.008

Guo, Y., McDonald Connor, C., Yang, Y., Roehring, A. D., \& Morrison, F. J. (2012). The effects of teacher qualification, teacher self-efficacy, and classroom practices on fifth graders' literacy outcomes. Elementary School Journal, 113, 3-24. https://doi.org/10.1086/665816

Holzberger, D., Philipp, A., \& Kunter, M. (2013). How teachers' self-efficacy is related to instructional quality: A longitudinal study. Journal of Educational Psychology, 105(3), 774-786. https://doi.org/10.1037/a0032198

Khan, S. A. (2012). The relationship between teachers' self-efficacy and students' academic achievement at secondary level. Language In India, 12(10), 436-448.

Klassen, R. M., \& Chui, M. M. (2010). Effects on teachers' self-efficacy and job satisfaction: Teacher gender, years of experience, and job stress. Journal of Educational Psychology, 102(3), 741-756. https://doi.org/10.1037/a0019237

McLaughlin, M. W., \& Marsh, D. D. (1978). Staff development and school change. Teachers College Record, 80, 70-94.

Midgley, C., Feldlaufer. H., \& Eccles, J. S. (1989). Change in teacher efficacy and student self- and task related beliefs in mathematics during the transition to junior high school. Journal of Educational Pschology, 81(2), 247-258. https://doi.org/10.1037/0022-0663.81.2.247

Mohamadi, F. S., \& Asadzadeh, H. (2012). Testing the mediating role of teachers' self-efficacy beliefs in the relationship between sources of efficacy information and students achievement. Asia Pacific Education Review, 13(3), 427-433. https://doi.org/10.1007/s12564-011-9203-8

Pajares. (2002). Overview of social cognitive theory and of self-efficacy.

Pintrich, P. R., \& Schunk, D. H. (1996). Motivation in Education: Theory, research, and applications.

Ross, J. A., \& Gray, P. (2006). Transformational leadership and teacher commitment to organizational values: The mediating effects of collective teacher efficacy. School Effectiveness and School Improvement, 17(2), 179-199. https://doi.org/10.1080/09243450600565795

Ross, J. A. (1992). Teacher efficacy and the effect of coaching on student achievement. Canadian Journal of Education, 17(1), 51-65. https://doi.org/10.2307/1495395

Ross, J. A. (1994). Beliefs That Make a Difference: The Origins and Impacts of Teacher Efficacy. Paper presented at the meeting of The Canadian Association for Curriculum Studies, Calgary, Alberta, Canada.

Rotter, J. B. (1966). Generalized expectancies for internal versus external control of reinforcement. Psychological Monographs, 80(1), 1-28. https://doi.org/10.1037/h0092976

Swanson, P. (2012). Second/foreign language teacher efficacy and its relationship to professional attrition. The Canadian Modern Language Review, 68(1), 78-101. https://doi.org/10.3138/cmlr.68.1.078

Thoonen, E. E., Sleegers, P. J., Oort, F. J., Peetsma, T. T., \& Geijsel, F. P. (2001). How to improve teaching practices: The role of teacher motivation, organizational factors, and leadership practices. Educational Administration Quarterly, 47(3), 496-536. https://doi.org/10.1177/0013161X11400185

Tschannen-Moran, M., Woolfolk-Hoy, A., \& Hoy, W. K. (1998). Teacher efficacy: Its meaning and measure. Review of Educational Research, 68, 202-248. https://doi.org/10.3102/00346543068002202

Von der Embse, N. P., Sandilos, L. E., Pendegast, L., \& Mankin, A. (2016). Teacher stress, teaching-efficacy, and job satisfaction in response to test-based educational accountability policies. Learning \& Individual Differences, 50, 308-317. https://doi.org/10.1016/j.lindif.2016.08.001

Woolfolk, A. E., Rosoff, B., \& Hoy, W. K. (1990). Teachers' sense of efficacy and their beliefs about managing students. Teaching \& Teacher Education, 6, 137-148. https://doi.org/10.1016/0742-051X (90)90031-Y 
Woolfolk Hoy, A., \& Davis, H. A. (2005). Teachers' sense of efficacy and its influence on the achievement of adolescents. In T. Urdan \& F. Pajares (Eds.), Adolescence and education: Volume V: Self-efficacy beliefs during adolescence (pp. 117-137). Greenwich, CT: Information Age.

Ware, H., \& Kitsantas, A. (2007). Teacher and collective efficacy beliefs as predictors of professional commitment. Journal of Educational Research, 100(5), 303-310. https://doi.org/10.3200/JOER.100.5. 303-310

Weinstein, C. S. (1988). Preservice teachers' expectations about the first year of teaching. Teaching and Teacher Education, 4, 31-40. https://doi.org/10.1016/0742-051X(88)90022-4

Wheatley, K. F. (2002). The potential benefits of teacher efficacy doubts for educational reform. Teaching and Teaching Education, 18, 5-22. https://doi.org/10.1016/S0742-051X(01)00047-6

Wyatt, M. (2016). Are they becoming more reflective and/or efficacious? A conceptual model mapping how teachers' self-efficacy beliefs might grow. Educational Review, 68(1), 114-137. https://doi.org/10.1080/ 00131911.2015 .1058754

Zee, M., \& Koomen, H. M. Y. (2016). Teacher self-efficacy and its effects on classroom processes, student academic adjustment, and teacher well-being. Review of Educational Research, 86(4), 981-1015. https://doi.org/10.3102/0034654315626801

Zee, M., Koomen, H. M. Y., Jellesma, F. C., Geerlings, J., \& de Jong, P. F. (2016). Inter- and intra-individual differences in teachers' self-efficacy: A multilevel factor exploration. Journal of School Psychology, 55(1), 39-56. https://doi.org/10.1016/j.jsp.2015.12.003

\section{Copyrights}

Copyright for this article is retained by the author(s), with first publication rights granted to the journal.

This is an open-access article distributed under the terms and conditions of the Creative Commons Attribution license (http://creativecommons.org/licenses/by/4.0/). 